\title{
BORDIR DAN PARIWISATA BUKITTINGGI DI SUMATERA BARAT
}

\author{
Oleh Yurisman
}

\begin{abstract}
ABSTRAK
Sumatera Barat merupakan salah satu daerah tujuan wisata nasional, yang memiliki objek dan daya tarik wisata yang beragam dan eksotik, baik alam maupun budaya. Menyadari potensi tersebut, Pemerintah Daerah Propinsi Sumatera Barat menetapkan pariwisata sebagai sektor andalan pembangunan daerah ke masa datang. Bukittinggi, sebagai salah satu daerah tujuan wisata utama Sumatera Barat, mengembangkan aspek fisik sekaligus pembinaan kerajinan bordir, sebagai salah satu bentuk kerajinan lokal yang potensial dijual sebagai souvenir pariwisata.

Kerajinan bordir Bukittinggi memiliki motif hias tradisional. Ada tiga bentuk produk bordir Bukittinggi, yaitu pertama, souvenir busana seperti: baju kebaya, baju koko, kaos oblong, selendang dan jilbab. Kedua, Souvenir perlengkapan atau lenan rumah tangga seperti: taplak meja, tatakan gelas, sarung bantal untuk kursi dan seprai. Ketiga Souvenir perlengkapan ibadah berupa mukena untuk shalat.

Motif hias yang digunakan adalah motif flora dan geometri. Motif-motif hias ini pada umumnya dikerjakan dengan teknik kerancang. Ada beberapa nama teknik kerancang yang dipakai dalam bordiran ini seperti : (1) kerancang Kursi; (2) kerancang Pahat; (3) kerancang Silang; (4) kerancang Roda-roda/ Lawah; (5) kerancang Sapu; (6) kerancang Sapu di tengah; (7) kerancang kacau/ Batu; (8) kerancang Papan; (9) kerancang balut; (10) kerancang potong; (11) kerancang rel; dan (12) kerancang mata ikan. Dalam sebuah produk bordir digabung berbagai macam kerancang, untuk tujuan variasi, menarik dan indah untuk dipandang.

Dalam perkembangannya, motif dan orientasi pemasaran bordir mengalami pergeseran. motif bordir saat ini telah mengikuti selera konsumen, dan pemasarannya tiddak semata pada pasar tradisonal di Bukittinggi melainkan juga diekspor ke manca negara, terutama Malaysia dan Brunei Darussalam.
\end{abstract}

Kata Kunci: pariwisata, bordir, souvenir.

\section{PENDAHULUAN}

Propinsi Sumatera Barat merupakan salah satu daerah tujuan wisata nasional, yang memiliki objek wisata yang beragam dan eksotik, baik alam maupun budaya. Potensi alam berupa panorama yang indah sangat didukung oleh seni budaya dan adat istiadat masyarakatnya yang masih kental, dan peninggalan budaya atau situs sejarah yang bernilai tinggi. Menyadari potensi tersebut, 
Pemerintah Daerah Propinsi Sumatera Barat telah menetapkan pariwisata sebagai sektor andalan pembangunan daerah ke masa datang.

Kota Bukittinggi merupakan salah satu daerah tujuan wisata di Sumatera Barat. Pembangunan sektor kepariwisataan Kota Bukittinggi tidak semata pada aspek fisik, tetapi juga dalam bentuk peningkatan pendapatan masyarakat melalui pembinaan kerajinan bordir, sebagai salah satu bentuk kerajinan lokal yang potensial dijual sebagai souvenir pariwisata.

Kerajinan bordir sudah dikenal oleh masyarakat Minangkabau, semenjak dibawa oleh bangsa Cipai suku Keling tahun 1818, bekas tantara Rafless di Bengkulu. Mereka tidak mau kembali ke negara asalnya, kemudian hijrah dan menetap Pariaman. (Wachid, 1997:135). Kehadiran kerajinan bordir di Kota Bukittinggi terjadi pada tahun 1960, yang dipelopori pengembangannya oleh Hajjah Rosma dari Pariaman. Kerajinan bordir berhubungan erat dengan kebutuhan masyarakat dalam berbagai Upacara Adat yang selalu digunakan sebagai bahan pakaian. Bahan pakaian untuk upacara adat tersebut terdiri dari: busana Bundo Kanduang (baju, selendang dan kodek/sarung), hiasan pelaminan, (terdiri dari tirai, langit-langit, dan banta gadang); dan hiasan carano.

Kerajinan bordir Bukittinggi memiliki berbagai macam bentuk motif hias, di antaranya: motif kaluak paku (keluk/ lengkung pakis); pucuak rabuang (pucuk rebung/ anak pohon bambu yang baru tumbuh); itiak pulang patang (itik/bebek pulang petang); dan saik ajik (potong wajik). Namun dalam perkembangannya sekarang, terjadi perubahan motif, yang disesuaikan mengikuti keinginan selera 
pemesannya. Dalam kasus ini, seringkali pembeli datang dengan membawa motif sendiri kemudian minta dibuatkan bordirannya.

\section{POTENSI PARIWISATA BUKITTINGGI}

Pariwisata budaya adalah kegiatan perjalanan yang bertujuan untuk melihat dan mempelajari adat istiadat, budaya, tatacara kehidupan masyarakat dan kebiasaan yang terdapat di daerah tujuan wisata. Konsep ini memperlihatkan bahwa pariwisata sangat terkait dengan motivasi wisatawan melakukan perjalanan yang umumnya ingin melihat aspek-aspek budaya seperti: (1) adat istiadat bangsa di daerah atau negara lain, (2) berbagai upacara adat, upacara keagamaan, dan upacara tradisional lainnya (3) pertunjukan kesenian seperti, festival tari, festival nyanyi dan festival drama, (4) keanekaragaman budaya masyarakat yang masih dianggap tradisional, dan (5) benda-benda bersejarah, monumen, peninggalan nenek moyang, candi, serta hasil-hasil budaya lainnya (Karyono dalam Djohan 2003:102).

Bukittinggi dengan masyarakatnya yang berbudaya Minangkabau memiliki beberapa objek dan daya tarik wisata budaya yang eksotik. Beberapa objek dan daya tarik wisata Bukittinggi itu adalah.

1. Pertunjukan tradisional, yang dipentaskan di gedung pertunjukan Medan Nan Balinduang, 100 meter dari objek wisata Jam Gadang. Materi yang ditampilkan tari-tarian dan musik tradisional Minangkabau, di antaranya: tari pasambahan, tari rantak, tari piring di atas beling, pencak silat, saluang jo dendang, talempong pacik dan instrument talempong yang digunakan sebagai 
pengiring tari. Selain itu, pertunjukan juga dipagelarkan di hotel-hotel dan tempat lain sesuai dengan kebutuhan konsumen.

2. Upacara Adat, yang dimodifikasi ke dalam pertunjukan, seperti upacara pengangkatan Penghulu, upacara dan pesta perkawinan, upacara turun mandi, upacara sunatan dan upacara khatam al-Quran.

3. Usaha kerajinan tangan khas Bukittinggi, menonjolkan ciri-ciri nilai budaya Minangkabau dalam setiap produknya, seperti Sulaman dan Bordir. Sekarang hasil dari usaha ini selain dijual di beberapa pasar tradisional di Kota Bukittinggi, juga sudah dikirim ke luar daerah Sumatera Barat, bahkan sudah diekspor keluar negeri seperti ke Malaysia dan Brunai Darussalam.

4. Museum. Ada beberapa museum di Kota Bukittinggi yaitu: museum budaya Bundo Kanduang (di lokasi Kebun Binatang), museum perang Tri Daya Eka Dharma (berlokasi di Taman Panorama dan Ngarai Sianok, Museum Bung Hatta (merupakan rumah kelahiran Bung Hatta)..

5. Jam Gadang, lambang Kota Bukittinggi, didirikan oleh Contreleur Roock Maker pada tahun 1926 di pusat Kota Bukittinggi. Bangunan ini dirancang oleh putra Minangkabau Jazid dan Sutan Gigi Ameh.

6. Benteng Fort De Kock, didirikan oleh Kapten Baver pada tahun 1826 masa Baron Hendrik Markus De Kock menjadi komandan Der Troepen dan wakil Gubernur Hindia Belanda. Benteng ini berada diatas bukit Jirek basis pertahanan kolonialis Belanda sejak Perang Paderi (1821-1827). Dari benteng ini kita bisa memandang keindahan Kota Bukittinggi dengan bebas. 
7. Lobang Jepang (1400 M), basis pertahanan tentara Jepang masa Perang Dunia II, dibuat melalui kerja paksa (rodi), berlokasi di taman Panorama.

Selain itu, potensi alam Bukittinggi dan sekitarnya sangat mendukung kota itu sebagai kota pariwisata. Banyak tempat yang dapat dikunjungi seperti Ngarai Sianok, alam pedesaan dengan kehidupan sehari-hari masyarakat (street culture), pertunjukan-pertunjukan kesenian (stage culture) dan kerajinan, serta konsep keluarga matriakat juga menarik untuk diketahui (Djohan, 2003:97).

\section{BORDIR SEBAGAI SOUVENIR}

Bentuk dan Teknik. Bentuk adalah segala apa yang dilihat, baik yang berupa titik, garis maupun bidang yang terukur besarnya, serta penggambaran suatu objek yang dapat dilihat oleh mata, kemudian kesannya dipindahkan pada pola bidang gambar melalui torehan, tempaan garis-garis dan warna (Rahardjo, 1987:43). Atau, penampilan produk secara visual, keseluruhan penampilan sebagai sosok yang menempati ruang serta unsur-unsur keindahan seperti warna, tekstur, glasur, yang memberikan kesan berat, halus, ringan dan kasar (Zai, 1997: 45). Teknik adalah kepandaian membuat sesuatu yang berkenaan dengan hasil industri, membuat atau melakukan sesuatu yang berhubungan dengan seni, metode atau sistem mengerjakan sesuatu, (KBBI, 2002:1158).

Merujuk kepada pendapat di atas, kerajinan bordir sebagai souvenir di Kota Bukittinggi pada umumnya dapat dibedakan kepada tiga bentuk. Pertama, souvenir busana seperti: baju kebaya, baju koko, kaos oblong, jilbab dan selendang. Kedua, souvenir untuk perlengkapan atau lenan rumah tangga seperti 
taplak meja dalam berbagai bentuk warna dan ukuran, sarung bantal untuk kursi tamu, seprai untuk perlengkapan kamar tidur dengan berbagai pilihan ukuran, dan tatakan gelas. Ketiga, souvenir untuk perlengkapan ibadah berupa mukena dalam berbagai pilihan motif dan warna.

Motif bordir khas Bukittinggi adalah kerancang. Teknik pengerjaannya menggunakan mesin jahit khusus yang digerakkan dengan kaki. Kerancang berarti kerawang atau lubang-lubang kecil dan halus yang terdapat pada sulaman, sujian atau bordiran (KBBI, 2002:549). Kegiatan mengerancang dilakukan mengikuti motif yang sudah digambar di atas kain. Kegiatan ini dilakukan dengan cara menjahit dengan mesin jahit konvensional atau mesin jahit tanpa menggunakan tenaga listrik.

Pekerjaan membuat kerancang yang bagus hanya dapat dilakukan oleh orang yang sudah terlatih dan berpengalaman, karena dalam proses pengerjaan teknik kerancang antara gerakan tangan dan gerakan kaki harus seirama untuk menghasilkan produk yang bermutu dan membuat motif-motif yang diinginkan sesuai dengan disain yang telah dipindahkan pada bahan.

Dalam pembuatan berbagai macam produk bordir, tentunya tidak terlepas dari motif. Motif merupakan ciri disain suatu karya atau pola pemikiran yang terdapat pada sebuah karya (Shadily, 1993: 2295). Motif juga berarti pola, corak, atau corak hiasan yang indah pada kain (KBBI, 2002: 756). Pengertian motif dalam konteks ini adalah pola atau corak yang dilukiskan di atas kain atau bahan yang akan dibordir. 
Pada umumnya bordir Bukittinggi bermotif tumbuhan (flora) seperti: daun, bunga, putik dan sulur. Motif itu biasanya dikreasi sendiri oleh pemilik usaha bordir, dengan berbagai variasi. Dalam hal ini, pengusaha sekaligus merangkap sebagai seorang disainer. Semua motif yang telah dijelaskan di atas, dalam pengerjaannya menggunakan berbagai teknik kerancang.

Ada 12 bentuk dasar kerancang dalam produk kerajinan bordir Bukittinggi, yaitu: (1) kerancang kursi; (2) kerancang pahat; (3) kerancang silang; (4) kerancang roda-roda/lawah; (5) kerancang sapu; (6) kerancang sapu di tengah; (7) kerancang kacau/batu; (8) kerancang papan; (9) kerancang balut; (10) kerancang potong; (11) kerancang rel; dan (12) kerancang mata ikan. Dari 12 bentuk dasar kerancang inilah pengusaha bordir mengembangkan kreatifitas. Penamaan kerancang didasarkan kepada motif yang dibuat. Pengembangan bentuk dasar itu sangat bergantung pada daya kreasi masing-masing pengusaha bordir.

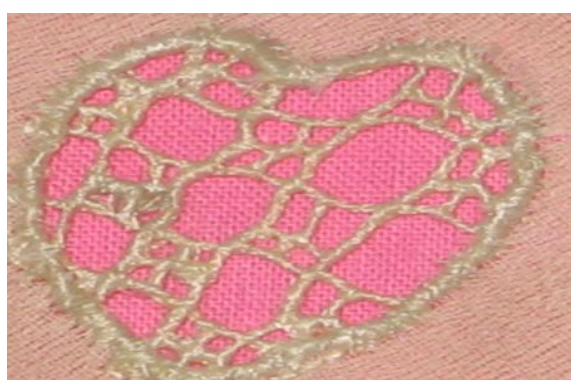

Gambar 1

Kerancang Kursi

Tidak diketahui siapa pencipta dan kapan motif-motif kerancang di atas digunakan pertama kali. Namun dalam sebuah produk bordir, pengusaha seringkali memadukan 3 sampai 5 motif. Hal itu dilakukan untuk menggunakan beberapa motif yang diinginkan dan sesuai. Hal ini dapat dilihat misalnya pada produk mukena. Dalam produk mukena ini biasanya digunakan 5 teknik motif 
seperti kerancang rel, kerancang batu/kacau, kerancang papan, kerancang balut, dan kerancang mata ikan yang dipadukan. Hasil perpaduan kelima motif kerancang tersebut menghasilkan sebuah produk yang indah dan bermutu. Semakin banyak motif kerancang yang terdapat pada sehelai mukena semakin tinggi pula harga jualnya.

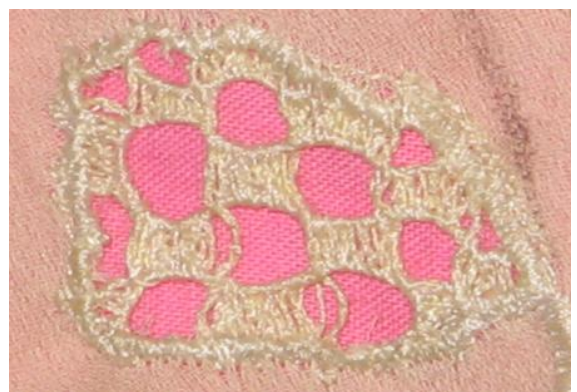

Gambar 2

Kerancang Papan

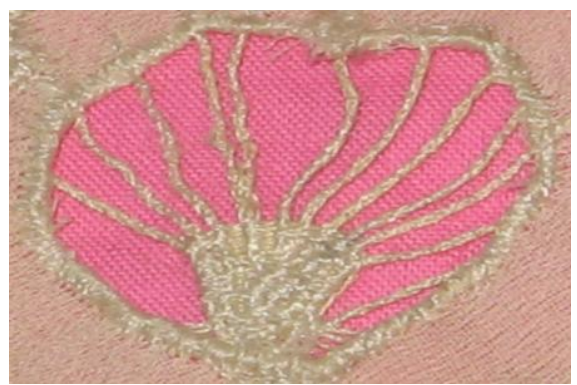

Gambar 3

Kerancang Sapu

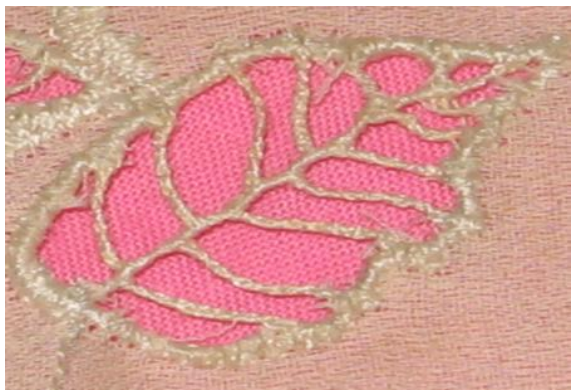

Gambar 4

Kerancang Balut 
Keindahan yang ada pada setiap produk kerajinan bordir Bukittinggi, dapat kita lihat pada komposisi warnanya. Pencampuran dan kombinasi berbagai warna sebuah produk sangat menarik. Keindahan inilah yang menjadi salah satu daya tarik bagi wisatawan (konsumen). Hal ini sejalan dengan pendapat Maran (2000:142) tentang keindahan, bahwa keindahan adalah suatu pengalaman yang unik dan khas. Secara objektif keindahan mengacu pada objek atau benda tertentu, seperti alam, karya seni yang memiliki daya tarik atau daya pesona.

\section{BENTUK-BENTUK PRODUK}

\section{A. Bentuk Souvenir Busana}

Usaha kerajinan sulaman dan bordir di Sumatera Barat umumnya dan Bukittinggi khususnya, bermula dari usaha rumahan (industri rumah tangga), dilakukan pada skala kecil, tenaga kerjanya tidak digaji, dan produksinya terbatas untuk keperluan peralatan seremonial adat Minangkabau, seperti pakaian pengantin, pakaian penghulu, dan pelaminan (Zubir 2004:74) Dalam perkembangannya, produsen mulai menghasilkan produk yang beragam, terutama dalam bentuk barang-barang cenderamata (souvenir).

Perkembangan itu dipengaruhi oleh perubahan selera konsumen. Konsumen sekarang lebih memilih busana yang praktis, mudah dipakai dan praktis dibawa kemana-mana. Kondisi tersebut menuntut pemilik usaha dan perajin untuk bisa mengkomodifikasi, mengembangkan dan menciptakan produk dengan disain-disain baru sesuai dengan selera pasar. Komodifikasi, sebagaimana dikatakan Barker (2005:517) sebagai proses kapitalisasi dimana objek, kualitas 
dan tanda-tanda diubah menjadi komoditas, yaitu sesuatu yang tujuan utamanya adalah terjual di pasar, mulai menjadi bagian dalam produksi bordir. Hal ini menyebabkan terjadinya akulturasi dalam produk kerajinan bordir yaitu proses sosial yang timbul bila suatu kelompok manusia dengan suatu kebudayaan tertentu dihadapkan dengan unsur-unsur dari suatu kebudayaan asing dengan sedemikian rupa, sehingga unsur-unsur kebudayaan asing itu lambat laun diterima dan diolah ke dalam kebudayaan sendiri (Koentjaraningrat, 2000:247).

Beberapa produk bordir yang sudah dikembangkan sesuai dengan tuntutan selera pasar pada saat di antaranya adalah baju kebaya, baju koko, kaos oblong, selendang, dan jilbab. Produk-produk tersebut sangat digemari oleh wisatawan, khususnya wisatawan asal Malaysia. Masing-masing bentuk produk tersebut memiliki kekhasannya masing-masing. Berikut ini akan dijelaskan tentang gambaran dari beberapa produk tersebut.

\section{Baju Kebaya}

Kebaya merupakan busana yang biasa digunakan oleh kaum wanita berupa blus berlengan panjang yang dipakai di sebelah luar kain atau sarung yang menutupi sebagian dari badan. Panjang kebaya ini berkisar sekitar pinggul atau sampai ke lutut (Achjadi. J,1972:3). Kebaya adalah baju perempuan bagian atas, berlengan panjang, dipakai dengan kain panjang (KBBI, 2002:521).

Produk kebaya Bukittinggi dihiasi motif bordir, biasanya pada belahan bagian depan, ujung lengan, dan bagian bawah dari kebaya. Hasil dari bordiran kebaya Bukittinggi yang dipasarkan ke konsumen biasanya ada yang sudah siap 
pakai dan juga ada yang berupa bahan dasar. Warna, jenis bahan dan motif bordiran kebaya yang ditawarkan juga beraneka ragam. Dengan demikian konsumen dapat memilih produk ini sesuai dengan selera mereka. Harga yang ditawarkan Rp 90.000,00-110.000,00- untuk pakaian atas, sedangkan harga untuk stelan kebaya pakaian bawah ditambah sekitar Rp 45.000,00. Penetapan harga pun beragam, tidak ada kesamaan antara pengusaha yang satu dengan yang lainnya. Artinya, penetapan harga dilakukan atas dasar kesepakatan antara konsumen dan penjual produk bordiran.

Berbagai bentuk motif dan model baju kebaya yang dibuat oleh perajin bordir Bukittinggi dapat dilihat pada gambar 13 berikut.

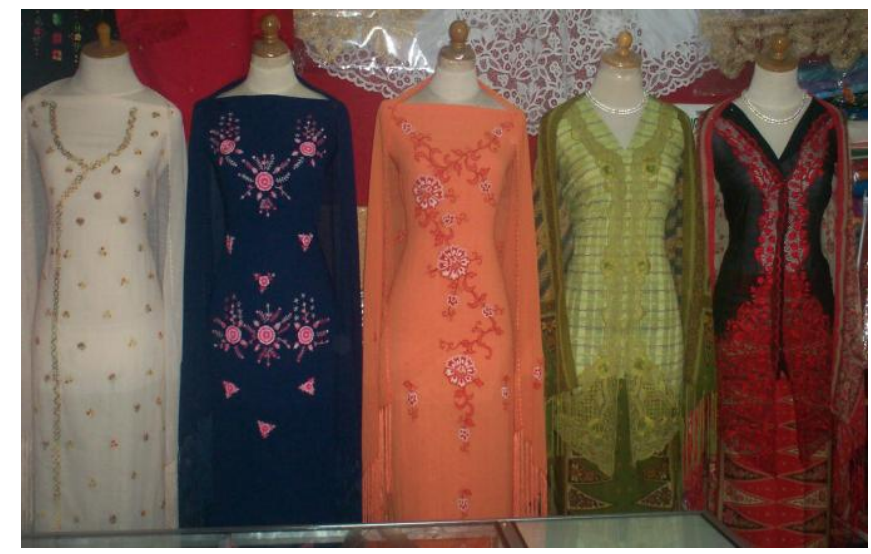

Gambar 5

Baju Kebaya siap pakai

\section{Baju Koko}

Baju Koko merupakan busana yang didesain untuk pria. Busana ini dirancang dengan bentuk blus berlengan panjang, kerah sanghai dengan belahan pada bagian depan sampai ujung bawah. Motif bordiran biasanya terdapat pada bagian depan memanjang dari bagian atas ke bawah pada sisi kiri dan sisi kanan, 
pada ujung lengan, bagian atas kantong dan pada keliling kerah. Warna yang ditawarkan tersedia dalam berbagai macam pilihan, mulai dari warna lembut sampai ke pilihan warna terang dan warna gelap. Biasanya warna motif bordir senada dengan warna bahan, tetapi dipilih warna yang lebih tua atau lebih muda.

Di Bukittinggi, Baju Koko ini banyak dipakai untuk kegiatan keagamaan yang bernuansa Islam, seperti untuk shalat Jum'at bagi kaum pria, shalat Hari Raya, takziah, hari-hari besar Islam dan pertemuan-pertemuan religius lainnya. Baju Koko ini juga dipakai untuk seragam kantor. Hal ini dapat dilihat pada setiap hari Jum'at. Pemerintah Kota Bukittinggi mewajibkan pegawainya untuk memakai Baju Koko sebagai seragam kerja dengan warna tertentu. Di sekolahsekolah Islam di Kota Bukittinggi, Baju Koko juga dipakai setiap hari sebagai seragam sekolah dengan membedakan warnanya pada hari-hari tertentu, dan bagi sekolah umum hanya mewajibkan siswanya untuk memakai baju ini pada setiap hari jum'at.

Harga Baju Koko ini di pasaran berkisar antara Rp 30.000,00-150.000,00 Produk Baju Koko ini banyak diminati, karena tidak saja diminati oleh wisatawan sebagai souvenir, tetapi juga diperlukan oleh masyarakat Kota Bukittinggi untuk kebutuhan-kebutuhan tertentu. Untuk melihat motif bordiran yang ada pada Baju Koko dapat dilihat pada gambar 14 dibawah ini. 


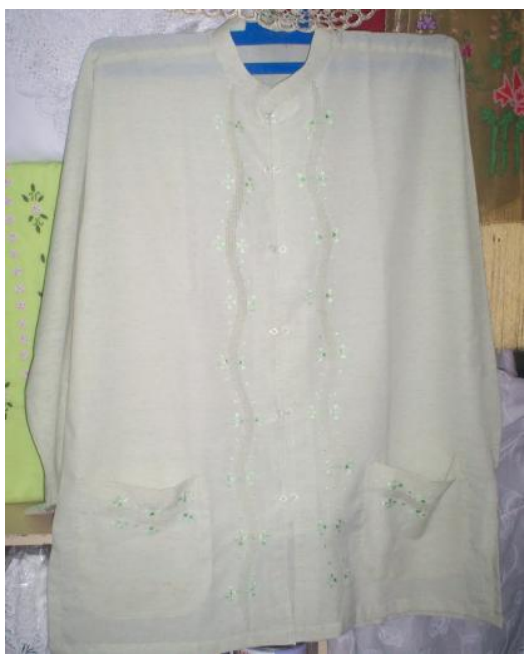

Gambar 6

Baju Koko dengan motif flora dan motif geometris

\section{Kaos Oblong}

Bordiran kaos oblong Bukittinggi bermotif Jam Gadang dan Rumah Gadang.

Produk ini tersedia dalam berbagai macam ukuran dan berbagai warna untuk dewasa dan anak anak, dengan harga yang relatif terjangkau oleh seluruh lapisan masyarakat yaitu sekitar Rp12.500,00-60.000,00-. Motif bordiran dengan gambar ikon-ikon keminangkabauan tersebut ditampilkan pada bagian depan. Motif bordiran yang ada pada kaos oblong ini dapat dilihat pada gambar 15 berikut.

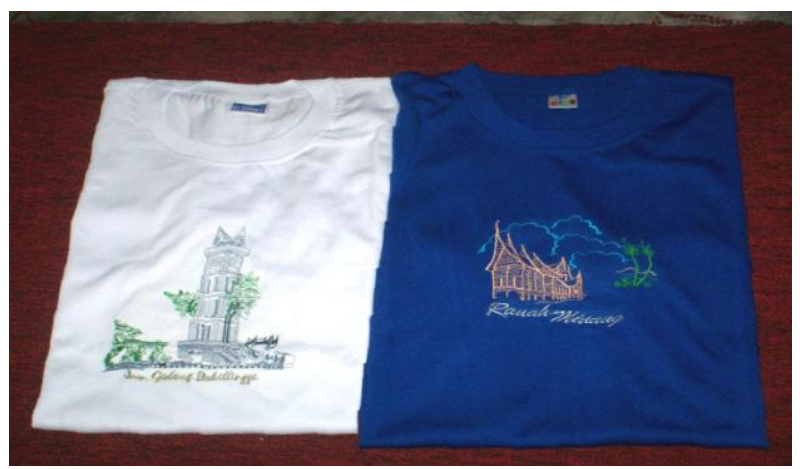

Gambar 7

Kaos oblong dengan bordiran Motif Jam Gadang dan Rumah Gadang 


\section{Selendang}

Busana wanita yang dipakai dalam suatu acara resmi biasanya dilengkapi dengan sehelai selendang. Di Bukittinggi, selendang dengan motif bordiran merupakan salah satu alternatif untuk dijadikan souvenir. Selendang dapat dibeli terpisah atau merupakan stelan dari baju kebaya dengan pilihan warna dan motif bordiran yang beragam. Motif yang digunakan untuk produk selendang ini biasanya motif flora dengan warna warna yang cerah dan variatif. Adapun harga yang ditawarkan berkisar antara Rp 70.000,00-1.700.000,00 bergantung kepada jenis bahan, motif dan teknik bordiran serta ukurannya. Motif yang digunakan dalam pembuatan selendang dapat dilihat pada gambar 16 berikut.

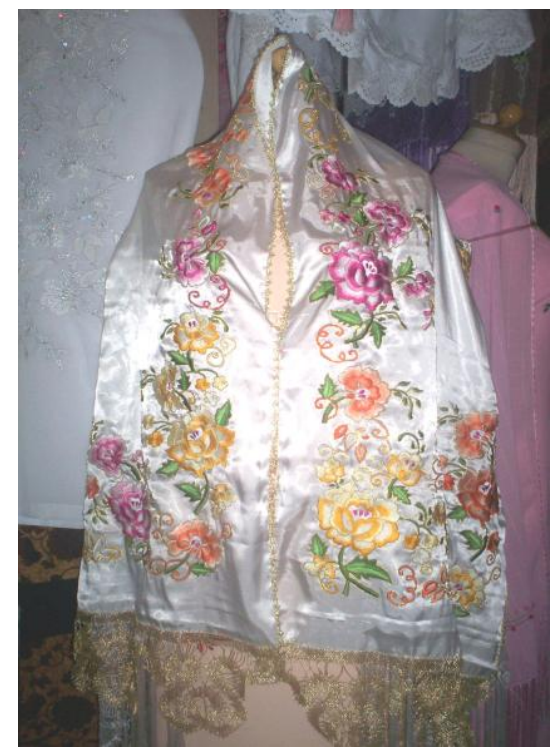

Gambar 8

Selendang dengan motif Flora

\section{Jilbab}

Jilbab merupakan pelengkap busana untuk wanita muslim atau disebut juga dengan kerudung, yang fungsinya untuk penutup kepala. Jilbab sangat disukai 
oleh wisatawan asal Malaysia karena wanitanya memakai kerudung sebagai busana dalam kegiatan sehari-harinya. Jilbab Bukittinggi khas, lebih indah, dan variatif dibanding jilbab produksi Malaysia. Harga jilbab atau kerudung ini berkisar antara Rp 30.000,00-75.000,00. Beberapa model dan bentuk jilbab dapat dilihat pada gambar 17 berikut.

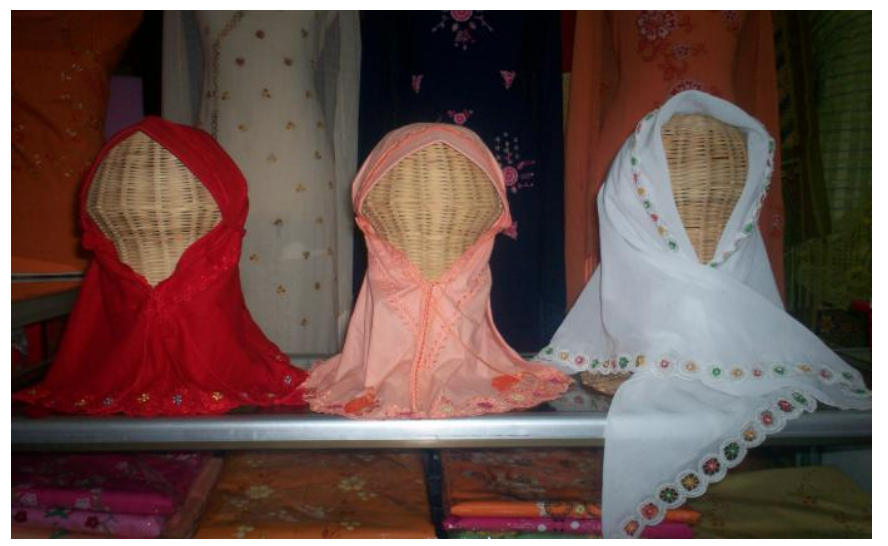

Gambar 9

Jilbab dengan motif flora dan geometris

\section{B. Bentuk Souvenir Lenan Rumah Tangga}

Ada beberapa bentuk kerajinan bordir untuk lenan atau perlengkapan rumah tangga yang dibuat oleh perajin bordir Bukttinggi, yaitu taplak meja, tatakan gelas, sarung bantal kursi, dan seprai.

\section{Taplak Meja}

Taplak meja bordir souvenir ada 4 (empat) bentuk, yakni berbentuk oval, lingkaran, empat persegi panjang dan bujur sangkar. Taplak meja ini disukai wisatawan karena bentuknya yang unik dan pengerjaan bordirnya dengan teknik 
kerancang penuh pada bahan. Harga yang ditawarkan Rp 30.000,00-100.000,00 Salah satu bentuk taplak meja adalah sebagaimana pada gambar 18 berikut.

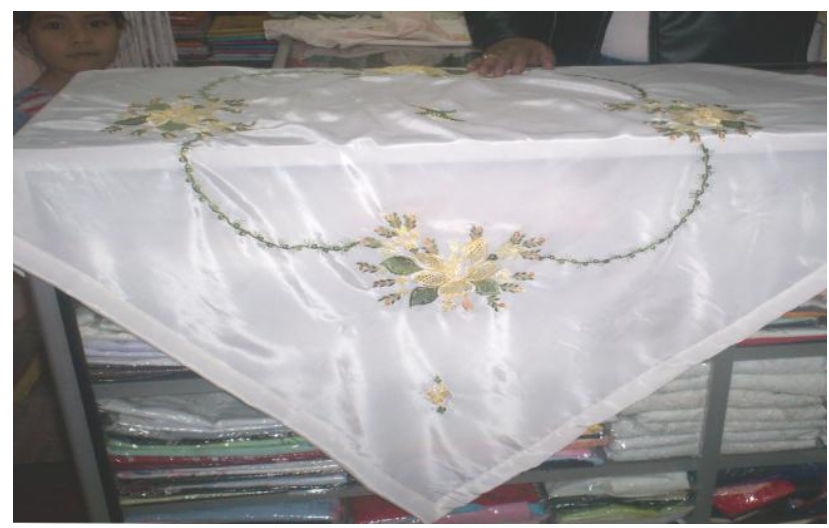

Gambar 10

Taplak meja berbentuk bujursangkar

\section{Tatakan Gelas}

Tatakan gelas dibuat dengan teknik kerancang bulat dengan diameter 10 cm. Tatakan gelas ini disukai wisatawan karena bentuknya yang menarik, ukurannya yang kecil dan tersedia dalam berbagai pilihan warna dan motif. Tatakan gelas ini dijual dengan harga Rp 10.000,- per lembarnya. Motif yang dipakai pada tatakan gelas ini adalah motif daun dan bunga yang dikerjakan dengan teknik kerancang kacau, kerancang potong dan teknik kerancang balut. Bentuk kerancang yang di gunakan pada tatakan gelas dapat dilihat pada gambar 19 berikut. 


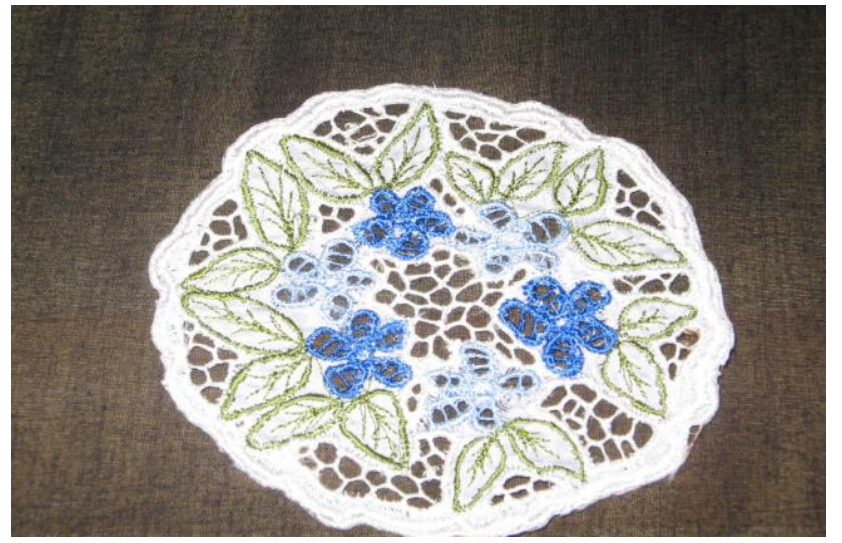

Gambar 11

Tatakan Gelas

\section{Sarung Bantal Kursi}

Sarung bantal kursi biasanya dipakai untuk mempercantik kursi ruangan tamu. Sarung bantal kursi yang diproduksi untuk souvenir berukuran 40 x $40 \mathrm{~cm}$ dengan motif flora. Sarung bantal kursi ini disukai wisatawan karena bentuknya yang indah dan produk ini tersedia dalam berbagai pilihan warna dan motif. Bahan yang biasanya digunakan untuk sarung bantal kursi ini adalah bahan lame, sehingga kelihatan lebih ekslusif. Untuk melihat keindahan pada sarung bantal kursi dapat dilihat pada gambar 20 berikut.

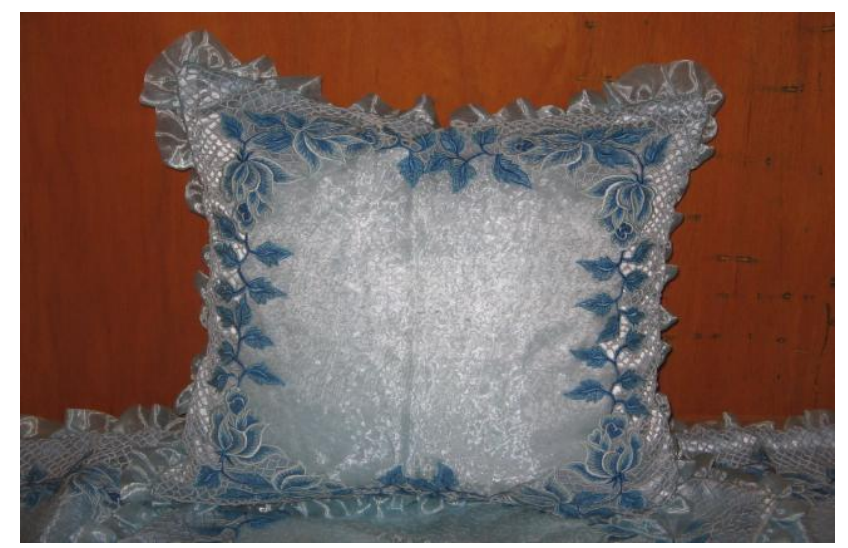

Gambar 12

Sarung bantal kursi 


\section{Seprai}

Seprai biasanya dilengkapi dengan sarung bantal dan sarung guling, baik sebagai perlengkapan harian maupun perlengkapan kamar penganten. Produk ini dapat ditemukan di toko toko yang menjual produk bordir dengan kisaran harga Rp 175. 000,00 -750.000,00 untuk seprai harian; dan $\operatorname{Rp} 750.000,00$ 2.500.000,00 untuk seprai perlengkapan kamar penganten. Harga bergantung kepada kualitas bahan, banyaknya motif, dan teknik bordir yang digunakan. Seprai untuk perlengkapan kamar penganten lebih mahal daripada seprai untuk keperluan sehari-hari. Salah satu bentuk seprai dapat dilihat pada gambar 21 berikut.

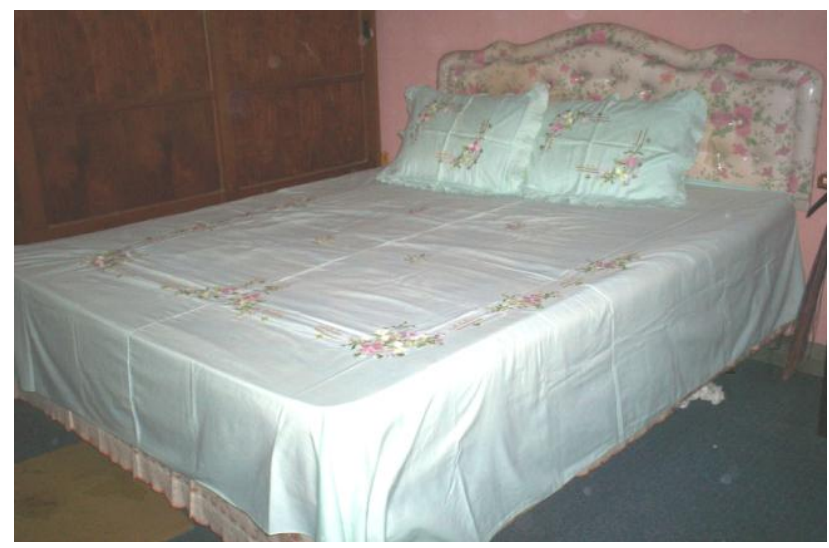

Gambar 13

Produk Seprai Untuk Harian

\section{Bentuk Souvenir Perlengkapan Ibadah}

Selain produk busana dan lenan rumah tangga, perajin bordir Bukittinggi juga membuat mukena sebagai souvenir. Selain disukai oleh wisatawan Nusantara mukena juga sangat diminati oleh wisatawan yang berasal dari negara jiran 
Malaysia dan Brunei Darussalam. Mereka menyukai produk bordir mukena Bukittinggi karena motifnya bagus dan khas. Kota Bukittinggi banyak kesamaan dengan Selangor, yaitu cara berbusana wanita yang selalu identik dengan kerudung (Padang Ekspres, 25 Sep. 2006)

Motif flora dengan pilihan bahan dan warna yang variatif, membuat mukena yang dihasilkan semakin indah dan menarik. Harga produk mukena pun bervariasi, tergantung jenis kain dan banyaknya motif yang digunakan. Harga mukena berkisar antara Rp 150.000,00-750.000,00. Semakin banyak jenis kerancang yang terdapat pada sehelai mukena maka harga jualnya juga semakin tinggi. Salah satu bentuk produk mukena dapat dilihat pada gambar 22 berikut.

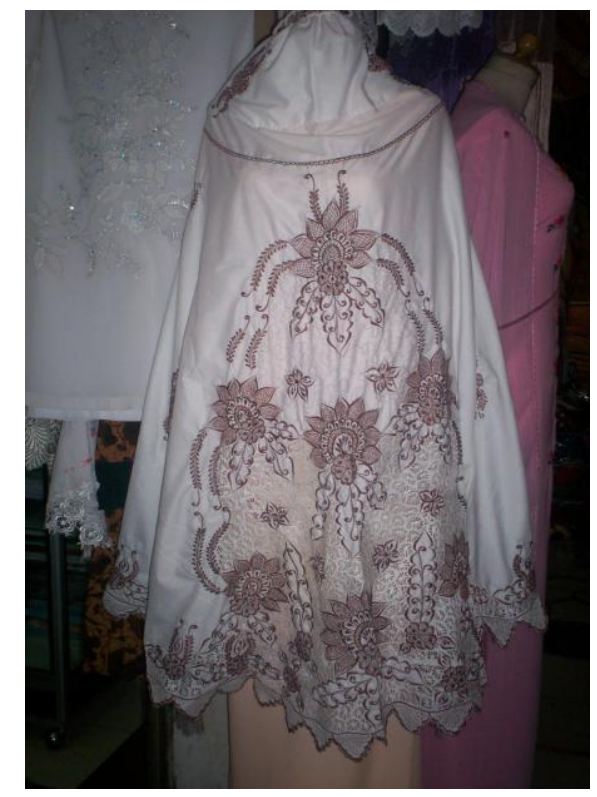

Gambar 14

Produk bordir Mukena dengan benang berwarna dengan motif flora berupa daun dan bunga 


\section{PENUTUP}

Sumatera Barat telah menjadikan Pariwisata sebagai sektor andalan pembangunan daerah ke masa depan. Bukittinggi sebagai salah satu daerah tujuan wisata utama Sumatera Barat juga telah berbenah diri, tidak saja dengan pembangunan fisik tetapi juga pembinaan sentra-sentra kerajinan, khususnya kerajinan bordir.

Kerajinan bordir, biasanya merupakan industri rumah tangga yang berorientasi produk berupa peralatan upacara adat, tetapi akibat pengaruh kepariwisataan ia berkembang menjadi produk souvenir yang eksotik. Selain perkembangan fungsi bordir tersebut, juga terjadi pergeseran motif bordir dari motif-motif tradisional ke motif-motif yang sesuai dengan selera konsumen. Tentu sasja semua itu merupakan efek dari kepariwisataan, yang secara finansial mendatangkan keuntungan kepada pengusaha dan perajin bordir itu sendiri. $* * *$

\section{DAFTAR PUSTAKA}

Achjadi, Judi. 1972. Pakaian Daerah Wanita Indonesia. Jakarta: Djambatan Barker, C. 2004. Cultural Studies, Teori dan Praktik. Yogyakarta: Kreasi Wacana Depdikbud. 1994. Kamus Besar Bahasa Indonesia, Edisi Kedua. Jakarta: Balai Pustaka

Depdikbud. 2002. Kamus Besar Bahasa Indonesia, Edisi Ketiga. Jakarta: Balai Pustaka

Djohan, E. dkk. 2003. Bukittinggi dan Pariwisata, Perspektif Ketenagakerjaan. Jakarta : Pustaka Sinar Harapan

Koentjaraningrat. 2000. Pengantar Ilmu Antropologi. Jakarta : Rineka Cipta

Maran, R R. 2000. Manusia dan Kebudayaan Dalam Perspektif Ilmu Budaya Dasar. Jakarta: Rineka Cipta 
Raharjo, J Budhi. 1987. Pendidikan Seni Rupa. Bandung: CV.Vrama Widya Dharma

Shadily, Hasan. 1982. Ensiklopedi Indonesia. Jakarta: Ichtiar Baru

Shadily, Hasan. 1993. Ensiklopedi Indonesia. Jakarta: Ichtiar Baru

Wachid, A. 1997. Hajah Rosma dan Nukilan Bordir Sumatera Barat. Padang: Citra Budaya Indonesia

Zai, Nursal. 1997. Desain Keramik. Padang: Diktat Kuliah IKIP Padang

Zubir, Z dan Lindayanti. 2004. Dari Ahong Sampai Ahmad: Studi Tentang kekerasan Politik dan Jebakan Kemiskinan Pada Level Akar Rumput. Yogyakarta: INSIST Press.

\section{BIODATA PENULIS}
Nama
: YURISMAN, S. Sn., M. Si.
Tempat/ Tanggal Lahir
: Lubuk Basung, Agam, 13 Agustus 1964
Pekerjaan
: Dosen STSI Padang Panjang
Alamat
: Wisma Indah II Blok A1 No. 1, Kampung Manggis, Padang Panjang, Sumatera Barat. 